\title{
Paradoxical differences in N-dynamics between Luxembourg soils: litter quality or parent material?
}

\author{
A. M. Kooijman · A. Smit
}

Received: 4 December 2008/Revised: 3 May 2009/ Accepted: 16 June 2009/Published online: 25 July 2009

(C) The Author(s) 2009. This article is published with open access at Springerlink.com

\begin{abstract}
To explore whether litter quality could alter differences in N-dynamics between soil types, we compared spruce and beech growing on soils with parent material sandstone and limestone, and beech and hornbeam on acid marl and limestone. We measured $\mathrm{pH}$, organic matter content, C:N ratio, soil respiration and net N-mineralization of the organic layer and the mineral topsoil in a laboratory incubation experiment and estimated gross $\mathrm{N}$-mineralization and immobilization with a simulation model. Species effects were restricted to the organic layer, but higher mass for low-degradable species was compensated by higher process rates for high-degradable ones, so $\mathrm{N}$-dynamics per square metre did not differ. Also, the mineral topsoil was not affected by litter quality, which may have been overruled by soil conditions. Forest soils formed from different parent materials, however, clearly differed in N-dynamics, although different from expectations for net N-mineralization. Sandstone showed low respiration and gross $\mathrm{N}$-mineralization, but net $\mathrm{N}$-mineralization was higher than expected, probably due to low microbial N-demand. In contrast, limestone, and to some extent acid marl, showed high respiration and gross $\mathrm{N}$-release, but lower net $\mathrm{N}$-mineralization than expected,
\end{abstract}

Communicated by A. Merino.

A. M. Kooijman $(\bowtie)$

Institute for Biodiversity and Ecosystem Dynamics,

University of Amsterdam, Nieuwe Achtergracht 166,

1018 WV Amsterdam, The Netherlands

e-mail: a.m.kooijman@uva.nl

\section{A. Smit}

Soil Sciences Centre, Alterra,

Wageningen University and Research Centre,

P.O. Box 47, 6700 AA Wageningen, The Netherlands because microbial immobilization was also high. Simulated gross $\mathrm{N}$-mineralization even showed a negative instead of positive correlation with net $\mathrm{N}$-mineralization, probably due to the strong increase in immobilization when gross $\mathrm{N}$-mineralization is high. The shift in microbial $\mathrm{N}$-demand may in turn be related to a more general shift from bacteria to fungi over $\mathrm{pH}$-gradients.

Keywords Acid marl · Beech · Hornbeam - Limestone . Mineralization $\cdot$ Respiration $\cdot$ Sandstone $\cdot$ Spruce

\section{Introduction}

Carbon and nitrogen cycling have always been crucial to the functioning of forest ecosystems and carbon sequestration, and significant advances have been made towards understanding the relationships between them (e.g. Schimel and Bennett 2004; Booth et al. 2005; Parton et al. 2007). Soil conditions favourable to decomposition, such as adequate moisture and high temperatures, generally increase gross $\mathrm{N}$-mineralization, and decrease time required to initiate net N-release (e.g. Reich et al. 1997; Parton et al. 2007). Also, over $\mathrm{pH}$-gradients, high litter turnover at high $\mathrm{pH}$ is generally associated with high $\mathrm{N}$-availability to the vegetation (Aerts and Chapin 2000; Ponge 2003; Schimel and Bennett 2004). However, in contrast to the above views, several field and laboratory studies actually showed the opposite, and calcareous soils showed generally lower instead of higher net N-mineralization than acid soils. Zöttle (1960) and Davy and Taylor (1974) found lower net N-mineralization in calcareous than in acid forest soils, even though they could not explain why. Verhoeven et al. (1990) and Kooijman and Hedenäs (2009) measured lower net $\mathrm{N}$-mineralization in base-rich than in acid peatlands, and 
Kooijman and Besse (2002) in dune grasslands. Naturally, $\mathrm{N}$-availability to the vegetation may not only depend on net $\mathrm{N}$-mineralization in the soil, as plant roots may take up organic $\mathrm{N}$ and actively compete with microbes for inorganic N (Schimel and Bennett 2004; Chapman et al. 2006). However, calcareous soil not only showed lower net $\mathrm{N}$-mineralization than acid soil, but also lower $\mathrm{N}$-content of beech seedlings or fresh beech litter (Wolters and Stickan 1991; Kooijman et al. 2008). In any case, even if plants find ways to circumvent reduced net $\mathrm{N}$-mineralization in calcareous soil, the combination of high biological activity and low net $\mathrm{N}$-mineralization is at least contradictory. Also, the combination of biological low activity, but high net $\mathrm{N}$-mineralization in acid soil may require further research.

To make it more complex, net $\mathrm{N}$-mineralization not only depends on soil conditions and microbial behaviour, but on litter quality as well. Litter quality is a major factor determining rates of decomposition, with initial N-content as key parameter (Swift et al. 1979; Parton et al. 2007). High carbon quality and N-content generally lead to rapid turnover and net N release (Scheu 1997; van der Krift and Berendse 2001), due to higher N-input, but also shorter time required to initiate net $\mathrm{N}$ release. Also, conifers often show lower net $\mathrm{N}$-mineralization than less recalcitrant hardwoods (e.g. Scott and Binkley 1997; Reich et al. 1997), even though differences are minor when compared on similar soils (Reich et al. 1997; Campbell and Gower 2000; Bagherzadeh 2004). It is thus likely that relationships between biological activity and net $\mathrm{N}$-mineralization are modified when different litters are applied.

The objective of this study was to further examine differences in N-dynamics between acid and calcareous soil, and to explore whether litter quality could possibly alter these response patterns. We selected species often used for litter quality studies (e.g. Swift et al. 1979; Laskowski et al. 1995; Aubert et al. 2003; Zhang and Makeschin 2004), and compared spruce (Picea abies L.) and beech (Fagus sylvatica L.) on sandstone and limestone, and beech and hornbeam (Carpinus betulus L.) on acid marl and limestone. We measured organic matter characteristics, soil respiration and net $\mathrm{N}$-mineralization in a laboratory incubation experiment, and estimated gross $\mathrm{N}$-mineralization and immobilization over the incubation period with a model, based on respiration, mineralization and $\mathrm{C}: \mathrm{N}$ ratios of substrate and microbes (Kooijman et al. 2008).

\section{Methods}

Study sites

The study sites were located in central Luxembourg, near Diekirch, with humid temperate climate and rainfall in all months. The species clearly differ in litter quality and $\mathrm{N}$-content. The coniferous spruce $(P$. abies L.) has generally high lignin:N ratios (e.g. Bagherzadeh 2004; Zhang and Makeschin 2004; Sah 2005). N-content of green needles collected during the experiment $(n=4)$, and determined with a CNS-analyzer (Westerman 1990), was relatively low with values of $15( \pm 1) \mathrm{mg} \mathrm{g}^{-1}$. $\mathrm{N}$-content in fresh needle litter was not measured, but probably ranged from 8 to $9 \mathrm{mg} \mathrm{g}^{-1}$ (Bagherzadeh 2004; Sah 2005). Beech (F. sylvatica L.) and hornbeam (C. betulus L.) are both deciduous species, but also clearly differ in litter quality. Hornbeam has generally lower lignin-N ratios and is higher-decomposable than beech (Laskowski et al. 1995; Aubert et al. 2003). In June, N-content of green leaves did not differ between beech and hornbeam, and was $25( \pm 2)$ and 24 $( \pm 2) \mathrm{mg} \mathrm{g}^{-1}$ respectively. However, in December, $\mathrm{N}$-content of fresh litter was higher for hornbeam, with $13.1( \pm 0.6) \mathrm{mg} \mathrm{g}^{-1}$, compared to $8.9( \pm 0.5) \mathrm{mg} \mathrm{g}^{-1}$ for beech (Kooijman and Martinez-Hernandez 2009).

Because hornbeam does not grow on acid sandstone, we compared species and parent materials pairwise: (1) spruce and beech on sandstone and limestone, and (2) beech and hornbeam on acid marl and limestone. The sandstone area $\left(49^{\circ} 52^{\prime} \mathrm{N}, 6^{\circ} 14^{\prime} \mathrm{E}\right.$, altitude $\left.410 \mathrm{~m}\right)$ was located on Jurassic sandstone, had Ah-E-Bw-C soil profile with signs of recent podzolisation, Mormoder humus form (Green et al. 1993), and Fago-Quercetum forest type (van der Werf 1991) with very sparse understory. Spruce and beech plots were selected in mature, homogeneous stands. The acid marl area $\left(49^{\circ} 49^{\prime} \mathrm{N}, 6^{\circ} 11^{\prime} \mathrm{E}\right.$, altitude $\left.340 \mathrm{~m}\right)$ was located on Triassic decalcified marl, with Ah-E-Bt-C soil profile, Mull humus form and Stellario-Carpinetum forest type with sparse understory. Characterististic species were Anemone nemorosa L. and Deschampsia cespitosa (L.) P. Beauv. Beech and hornbeam plots were selected in mixed forests, in homogeneous plots of at least three mature trees. The limestone area $\left(49^{\circ} 50^{\prime} \mathrm{N}, 6^{\circ} 15^{\prime} \mathrm{E}\right.$, altitude $270 \mathrm{~m}$ ) was located on Triassic dolomitic limestone, with Ah-C soil profile, Mull humus form and MelicoFagetum forest type. Characteristic species were Mercurialis perennis L. and Orchis mascula (L.) L. Spruce plots were selected in mature, homogeneous stands, with very sparse understory. Beech and hornbeam plots were selected in mixed forests, in homogeneous plots surrounded by at least three mature trees. Understory was species-rich and had relatively high cover, especially under hornbeam. Litter input of spruce was not measured; for beech and hornbeam, litter input did not differ between species and sites, and was $391( \pm 38) \mathrm{g} \mathrm{m}^{-2}$ under beech, and $397( \pm 62) \mathrm{g} \mathrm{m}^{-2}$ under hornbeam (Kooijman and Martinez-Hernandez 2009). 
Incubation experiment

Samples for the incubation experiment were collected in June, in four randomly selected plots in each forest. The organic layer was sampled in $25 \mathrm{~cm} \times 25 \mathrm{~cm}$. The mineral topsoil was sampled in three metal rings of $5 \mathrm{~cm}$ depth, which comprised the Ah completely. This may have underestimated actual contribution of the mineral soil on acid marl and limestone, but since we concentrated on process rates, we choose the most active layer. Also, response patterns did not differ when $10 \mathrm{~cm}$ depth was used (Kooijman and Martinez-Hernandez 2009). Fresh weight and gravimetric moisture content were determined, and dry weight and bulk density calculated. After drying (48 h at $70^{\circ} \mathrm{C}$ for organic and $105^{\circ} \mathrm{C}$ for mineral samples) and grinding of subsamples, $\mathrm{C}$ and $\mathrm{N}$ contents were determined with a CNS analyzer (Westerman 1990).

Net $\mathrm{N}$-mineralization and respiration were measured in a 1-month laboratory incubation experiment. Samples were homogenized by hand, and roots were removed. Fresh samples were put into large Petri dishes and brought to optimal gravimetric moisture levels (300\% for organic and $50 \%$ for mineral soil samples; Tietema 1992). Petri dishes were stored at $20^{\circ} \mathrm{C}$ in the dark, in slightly open polyethylene bags with moist paper; moisture content was checked and replenished when necessary. Ammonium and nitrate concentrations of fresh and incubated samples were extracted with $50 \mathrm{ml} 1 \mathrm{M} \mathrm{KCL}$ solution, using the equivalent of 1.5 and $4.5 \mathrm{~g}$ dry material for organic and mineral samples respectively, and measured on a continuous-flow analyzer (Westerman 1990). Net N-mineralization was calculated from differences between incubated and fresh samples. Nitrification was calculated as the amount of nitrate released over the incubation period, expressed as percentage of net $\mathrm{N}$-mineralization.

Respiration was measured at the start and end of the incubation experiments and at two intervals in between, and was approximately linear during the incubation period. Fresh material (the equivalent of $5 \mathrm{~g}$ dry for organic and 10-15 g dry for mineral samples) was placed in an open glass jar and stored in slightly open polyethylene bags with moist paper in the dark at $20^{\circ} \mathrm{C}$ for 1 month. The containers were weighed at weekly intervals in order to check moisture content and replenished when necessary. During measurements, the jars were closed and air samples were extracted by needle. $\mathrm{CO}_{2}$-concentrations were measured three times by injecting air samples into a Carlo Erba Varian gas chromotograph (Tietema 1992). $\mathrm{CO}_{2}$-production rates were calculated from the increase in $\mathrm{CO}_{2}$-concentration during the day, the volume of the head space and sample dry weight. Total $\mathrm{CO}_{2}$-production over the incubation period was calculated, based on its duration and $\mathrm{CO}_{2}$-production at start and end of the experiment.
Statistical analysis

Statistical analysis was conducted separately for sprucebeech on sandstone and limestone, and beech-hornbeam on acid marl and limestone. Because we used data of beech on limestone in comparison with both spruce and hornbeam, we used Bonferroni corrections to compensate for this; differences were considered to be significant at probability values below 0.025 , instead of 0.05 . In both comparisons, differences between species and parent materials in organic matter characteristics, soil respiration and $\mathrm{N}$-dynamics were tested with two-way analysis of variance, with species and site as independent factor (SAS Institute Inc. 1985). Interactions between species and sites were mostly not significant, and are not further treated. Differences between individual mean values were tested with least square means tests.

Modelled gross $\mathrm{N}$-mineralization and immobilization

To explore whether differences in net $\mathrm{N}$-mineralization between species or sites could be explained by changes in gross release and microbial immobilization, a theoretical model was used (Kooijman et al. 2008), based on equations of C and N dynamics of Berendse et al. (1989) and Tietema and Wessel (1992). Because gross release was not actually measured, the model should be seen as indicative rather than absolute. Microbial growth efficiency $\left(e_{\mathrm{C}}\right)$, the fraction of gross $\mathrm{C}$-release used for microbial assimilation, and key parameter in the allocation of $\mathrm{C}$ and $\mathrm{N}$ from organic matter to microbes (Schimel 1988; Tietema and Wessel 1992), was calculated according to Kooijman et al. (2008), based on measured values of respiration $(Q)$, net $\mathrm{N}$-mineralization $(\mathrm{NM}), \mathrm{N}: \mathrm{C}$ ratios of substrate $\left(\mathrm{NC}_{\mathrm{S}}\right)$ and microbes $\left(\mathrm{NC}_{\mathrm{M}}\right)$ as:

$e_{\mathrm{C}}=\left[\left(\mathrm{NC}_{\mathrm{S}} \times Q\right)-\mathrm{NM}\right] /\left[\left(\mathrm{NC}_{\mathrm{M}} \times Q\right)-\mathrm{NM}\right]$

Using the estimated $e_{\mathrm{C}}$ values, gross $\mathrm{N}$-mineralization (GN) was calculated as:

$\mathrm{GN}=\left[1 /\left(1-e_{\mathrm{C}}\right)\right] \times \mathrm{NC}_{\mathrm{S}} \times Q$

Immobilization $(I)$ was calculated as:

$I=\left[e_{\mathrm{C}} /\left(1-e_{\mathrm{C}}\right)\right] \times \mathrm{NC}_{\mathrm{M}} \times Q$

Microbial C:N ratios were not actually measured in the present experiment, but mean values and standard deviations were taken from Kooijman et al. (2008), who conducted a research in the same area; microbial C:N ratios in the organic layer were $7.9( \pm 2.2), 8.8( \pm 1.7)$ and 7.0 $( \pm 0.8)$ on sandstone, acid marl and limestone respectively, and in the mineral topsoil $8.8( \pm 2.9), 8.0( \pm 1.8)$ and 6.2 $( \pm 2.3)$.

Mean values and standard deviations of modelled gross $\mathrm{N}$-mineralization and immobilization were calculated for 
different species, parent materials and horizons, based on full four-factor perturbation tests (Henderson-Sellers and Henderson-Sellers 1993). Each perturbation test was based on 16 runs with mean values of the four input parameters (respiration, net $\mathrm{N}$-mineralization and $\mathrm{N}$ : $\mathrm{C}$ ratios of substrate and microbes), plus or minus one standard deviation.

In order to explore potential differences between species and parent materials in total $\mathrm{N}$-dynamics and contribution of different soil layers, values of organic layer and mineral topsoil were tentatively combined. Potential relationships between gross $\mathrm{N}$-mineralization, immobilization and net $\mathrm{N}$-mineralization were tested with linear regression, based on mean values for each of the seven forest sites. On acid marl and especially limestone, the actual contribution of the mineral topsoil to total N-dynamics may be higher than on sandstone, because deeper layers may be important as well. To test whether a potential underestimation of the mineral soil on these parent materials could change the results, regression analysis was also applied with adjusted values. For acid marl, we chose multiplication of mineral topsoil values with factor 1.5 or 2 , and for limestone with factor 2 or 3 .

\section{Results}

Organic matter characteristics and process rates

In the comparison between spruce and beech, on sandstone and limestone, species effects were mainly significant for the organic layer (Table 1). Spruce had lower $\mathrm{pH}$ and higher mass of the organic layer than beech (Table 2). The organic layer of beech, however, had higher rates of respiration and net $\mathrm{N}$-mineralization. Also, efficiency of net $\mathrm{N}$-mineralization per unit $\mathrm{C}$ respired was higher for beech than for spruce, in both organic layer and mineral topsoil. Nitrification did not differ between species, but was high in all sites and soil layers, with values generally above $78 \%$.

Differences between sandstone and limestone were significant for both organic layer and mineral topsoil, except for nitrification, which was not affected at all, and net $\mathrm{N}$-mineralization rates in the mineral topsoil, which did not differ between sites. Sandstone had generally lower $\mathrm{pH}$, and higher mass of the organic layer than limestone, and higher $\mathrm{C}: \mathrm{N}$ ratio in the mineral topsoil. In contrast, limestone had higher SOM in the mineral topsoil, and higher respiration rates in both organic layer and mineral topsoil. However, sandstone had higher rates of net N-mineralization, at least in the organic layer and net $\mathrm{N}$-mineralization per unit $\mathrm{C}$ respired in both organic layer and mineral topsoil.

In the comparison between beech and hornbeam, on acid marl and limestone, species effects were significant for
SOM and rates of respiration (Table 3). Beech had higher SOM in both organic layer and mineral topsoil, and hornbeam higher respiration rates, at least in the organic layer (Table 4). In the mineral topsoil, however, respiration rates were higher for beech.

Differences between acid marl and limestone were significant in both organic layer and mineral topsoil. Limestone had higher $\mathrm{pH}$ in both soil layers, and higher $\mathrm{C}: \mathrm{N}$ ratios and rates of respiration in the organic layer. Limestone also showed higher nitrification in the mineral topsoil, with values of $85-101 \%$, compared to $36-46 \%$ on acid marl. However, net $\mathrm{N}$-mineralization rates were significantly higher on acid marl.

Respiration, gross N-mineralization, net $\mathrm{N}$-mineralization and immobilization

Differences between spruce and beech in (modelled) N-dynamics were relatively unimportant, and partly reflected in the organic layer, but not at all in the mineral topsoil (Fig. 1). In the organic layer, spruce had higher respiration and gross $\mathrm{N}$-mineralization per square metre than beech on both sandstone and limestone, despite low process rates, because mass was so high. However, net $\mathrm{N}$-mineralization per square metre did not differ between species, because beech compensated low mass with higher process rates, but also with lower immobilization.

In contrast to species, parent materials clearly differed in $\mathrm{N}$-dynamics. In the organic layer, which was more extensive on sandstone than on limestone, respiration and gross $\mathrm{N}$-mineralization were more or less the same. However, net $\mathrm{N}$-mineralization per square metre was much higher on sandstone, because immobilization was much lower than on limestone. In the mineral topsoil, as expected, respiration and gross $\mathrm{N}$-mineralization were higher on limestone than on sandstone. However, because immobilization was also high, this did not lead to higher net N-mineralization.

In the comparison between beech and hornbeam, (modelled) N-dynamics were hardly affected by species, although the organic layer was generally more important for beech than for hornbeam (Fig. 2). Parent materials showed more differences in $\mathrm{N}$-dynamics, even though organic layer and mineral topsoil had opposite responses. In the organic layer, respiration, gross $\mathrm{N}$-mineralization and immobilization were generally higher on acid marl, while limestone had higher values in the mineral topsoil. Net N-mineralization, however, was lower on limestone.

Total values of organic layer and mineral topsoil combined were further used to explore overall differences in N-cycling between sites and species (Fig. 3). Total gross $\mathrm{N}$-mineralization and immobilization showed a clear positive relationship $\left(R^{2}=0.99\right)$, and both factors increased from sandstone to acid marl and limestone. 
Table 1 Two-way ANOVA of the differences in soil characteristics of four Luxembourg forests with different species (spruce and beech) and parent materials (sandstone and limestone), with tree species and parent material as independent factors

\begin{tabular}{|c|c|c|c|c|}
\hline & $\begin{array}{l}\text { Organic } \\
\text { Species }\end{array}$ & $\begin{array}{l}\text { Layer }(n=16) \\
\text { Site }\end{array}$ & $\begin{array}{l}\text { Mineral } \\
\text { Species }\end{array}$ & $\begin{array}{l}\text { Topsoil }(n=16) \\
\text { Site }\end{array}$ \\
\hline $\mathrm{pH}$ & 0.0004 & 0.0001 & 0.9189 & 0.0001 \\
\hline $\operatorname{SOM}\left(\mathrm{kg} \mathrm{m}^{-2}\right)$ & 0.0001 & 0.0001 & 0.5244 & 0.0200 \\
\hline $\mathrm{C}: \mathrm{N}$ ratio & 0.0024 & 0.0001 & 0.4229 & 0.0005 \\
\hline Respiration rates $\left(\mathrm{g} \mathrm{kg}^{-1} \mathrm{day}^{-1}\right)$ & 0.0010 & 0.0061 & 1.0000 & 0.0001 \\
\hline Net $\mathrm{N}$-mineralization rates $\left(\mathrm{g} \mathrm{kg}^{-1}\right.$ day $\left.^{-1}\right)$ & 0.0001 & 0.0006 & 0.0106 & 0.0846 \\
\hline Net $\mathrm{N}$-mineralization per unit $\mathrm{C}$ respired & 0.0131 & 0.0004 & 0.0033 & 0.0004 \\
\hline Nitrification $(\%)$ & 0.0678 & 0.4833 & 0.6876 & 0.0610 \\
\hline
\end{tabular}

Interactions between species and parent materials were mostly not significant, and are not given. Potential effects on $\mathrm{pH}$ and $\mathrm{C}$ and $\mathrm{N}$-dynamics in a laboratory incubation experiment are given as probability values; due to Bonferroni corrections, only $P$-values below 0.025 are significant

Table 2 Soil characteristics and $\mathrm{C}$ and N-dynamics in a laboratory incubation experiment with samples from Luxembourg forests with different species (spruce and beech) and parent materials (sandstone and limestone)

\begin{tabular}{|c|c|c|c|c|c|c|}
\hline & \multicolumn{2}{|l|}{$\mathrm{pH}-\mathrm{KCl}$} & \multicolumn{2}{|c|}{$\operatorname{SOM}\left(\mathrm{kg} \mathrm{m}^{-2}\right)$} & \multicolumn{2}{|c|}{$\mathrm{C}: \mathrm{N}$ ratio $\left(\mathrm{g} \mathrm{g}^{-1}\right)$} \\
\hline & Organic & $\mathrm{Ah}$ & Organic & $\mathrm{Ah}$ & Organic & $\mathrm{Ah}$ \\
\hline \multicolumn{7}{|l|}{ Spruce } \\
\hline Sandstone & $3.2(0.1)^{\mathrm{a}}$ & $3.2(0.1)^{\mathrm{a}}$ & $8.0(1.2)^{\mathrm{c}}$ & $3.6(0.7)^{\mathrm{a}}$ & $26(2)^{\mathrm{b}}$ & $26(5)^{\mathrm{b}}$ \\
\hline Limestone & $5.5(0.4)^{\mathrm{c}}$ & $5.9(0.7)^{\mathrm{b}}$ & $3.3(1.2)^{\mathrm{b}}$ & $5.2(0.5)^{\mathrm{b}}$ & $26(2)^{\mathrm{b}}$ & $16(2)^{\mathrm{a}}$ \\
\hline \multicolumn{7}{|l|}{ Beech } \\
\hline Sandstone & $4.1(0.1)^{\mathrm{b}}$ & $3.4(0.1)^{\mathrm{a}}$ & $1.3(0.7)^{\mathrm{a}}$ & $4.3(1.3)^{\mathrm{ab}}$ & $21(1)^{\mathrm{a}}$ & $24(7)^{\mathrm{b}}$ \\
\hline \multirow[t]{2}{*}{ Limestone } & $5.7(0.1)^{\mathrm{c}}$ & $5.8(0.7)^{\mathrm{b}}$ & $0.5(0.2)^{\mathrm{ab}}$ & $5.0(0.6)^{\mathrm{b}}$ & $39(3)^{\mathrm{c}}$ & $15(2)^{\mathrm{a}}$ \\
\hline & \multicolumn{2}{|c|}{ Respiration $\left(\mathrm{mg} \mathrm{kg}^{-1} \mathrm{day}^{-1}\right)$} & \multicolumn{2}{|c|}{ Net $\mathrm{N}$-mineralization $\left(\mathrm{mg} \mathrm{kg}^{-1}\right.$ day $\left.^{-1}\right)$} & \multicolumn{2}{|c|}{$\mathrm{NM}$ per unit $\mathrm{C}$ respired $\left(\mathrm{mg} \mathrm{g}^{-1}\right)$} \\
\hline \multicolumn{7}{|l|}{ Spruce } \\
\hline Sandstone & $458(36)^{\mathrm{a}}$ & $25(3)^{\mathrm{a}}$ & $9(2)^{\mathrm{ab}}$ & $0.0(0.0)^{\mathrm{a}}$ & $20(5)^{\mathrm{bc}}$ & $12(9)^{\mathrm{a}}$ \\
\hline Limestone & $1,005(208)^{\mathrm{ab}}$ & $68(14)^{\mathrm{b}}$ & $3(6)^{\mathrm{a}}$ & $0.5(0.6)^{\mathrm{ab}}$ & $2(5)^{\mathrm{a}}$ & $6(5)^{\mathrm{a}}$ \\
\hline \multicolumn{7}{|l|}{ Beech } \\
\hline Sandstone & $1,160(326)^{b c}$ & $33(13)^{\mathrm{a}}$ & $37(6)^{\mathrm{c}}$ & $1.3(0.6)^{\mathrm{b}}$ & $35(11)^{\mathrm{c}}$ & $45(11)^{\mathrm{b}}$ \\
\hline Limestone & $1,627(476)^{\mathrm{c}}$ & $59(14)^{\mathrm{b}}$ & $15(9)^{\mathrm{b}}$ & $0.3(0.5)^{\mathrm{a}}$ & $11(10)^{\mathrm{ab}}$ & $9(5)^{\mathrm{a}}$ \\
\hline
\end{tabular}

Mean values $(n=4)$ and standard deviations. Different letters indicate significant differences between species and/or parent materials for a particular soil parameter $(P<0.025$, due to Bonferroni corrections)

$S O M$ soil organic matter, $N M$ per unit $C$ respired net $\mathrm{N}$-mineralization per unit $\mathrm{C}$ respired, organic organic layer, Ah mineral topsoil

Table 3 Two-way ANOVA of the differences in soil characteristics of four Luxembourg forests with different species (beech and hornbeam) and parent materials (acid marl and limestone), with tree species and parent material as independent factors

\begin{tabular}{lllll}
\hline & $\begin{array}{l}\text { Organic } \\
\text { Species }\end{array}$ & $\begin{array}{l}\text { layer }(n=16) \\
\text { Site }\end{array}$ & $\begin{array}{l}\text { Mineral } \\
\text { Species }\end{array}$ & $\begin{array}{c}\text { topsoil }(n=16) \\
\text { Site }\end{array}$ \\
\hline $\mathrm{pH}$ & 0.0722 & 0.0001 & 0.6588 & 0.0007 \\
$\mathrm{SOM}\left(\mathrm{kg} \mathrm{m}^{-2}\right)$ & 0.0180 & 0.4577 & 0.0051 & 0.1903 \\
$\mathrm{C}: \mathrm{N}$ ratio & 0.2773 & 0.0001 & 0.0556 & 0.0225 \\
Respiration rates $\left(\mathrm{g} \mathrm{kg}^{-1} \mathrm{day}^{-1}\right)$ & 0.0038 & 0.0241 & 0.0241 & 0.6524 \\
Net N-mineralization rates $\left(\mathrm{mg} \mathrm{kg}^{-1} \mathrm{day}^{-1}\right)$ & 0.2225 & 0.1100 & 0.2160 & 0.0016 \\
Net N-mineralization per unit C respired & 0.1848 & 0.2103 & 0.0766 & 0.0447 \\
Nitrification $(\%)$ & 0.0541 & 0.8423 & 0.0200 \\
\hline
\end{tabular}

Interactions between species and parent materials were mostly not significant, and are not given. Potential effects on $\mathrm{pH}$ and $\mathrm{C}$ and $\mathrm{N}$-dynamics in a laboratory incubation experiment are given as probability values; due to Bonferroni corrections, only $P$-values below 0.025 are significant 
Table 4 Soil characteristics and $\mathrm{C}$ and N-dynamics in a laboratory incubation experiment with samples from Luxembourg forests with different species (beech and hornbeam) and parent materials (acid marl and limestone)

\begin{tabular}{|c|c|c|c|c|c|c|}
\hline & \multicolumn{2}{|l|}{$\mathrm{pH}-\mathrm{KCl}$} & \multicolumn{2}{|c|}{$\operatorname{SOM}\left(\mathrm{kg} \mathrm{m}^{-2}\right)$} & \multicolumn{2}{|c|}{$\mathrm{C}: \mathrm{N}$ ratio $\left(\mathrm{g} \mathrm{g}^{-1}\right)$} \\
\hline & Organic & $\mathrm{Ah}$ & Organic & $\mathrm{Ah}$ & Organic & $\mathrm{Ah}$ \\
\hline \multicolumn{7}{|l|}{ Beech } \\
\hline Acid marl & $4.9(0.3)^{\mathrm{a}}$ & $4.1(0.3)^{\mathrm{a}}$ & $0.7(0.3)^{\mathrm{b}}$ & $4.3(1.3)^{\mathrm{ab}}$ & $34(1)^{\mathrm{b}}$ & $17(2)^{\mathrm{b}}$ \\
\hline Limestone & $5.7(0.1)^{\mathrm{b}}$ & $5.8(0.7)^{\mathrm{c}}$ & $0.6(0.2)^{\mathrm{ab}}$ & $5.0(0.6)^{\mathrm{b}}$ & $39(3)^{\mathrm{c}}$ & $15(2)^{\mathrm{ab}}$ \\
\hline \multicolumn{7}{|l|}{ Hornbeam } \\
\hline Acid marl & $4.7(0.1)^{\mathrm{a}}$ & $4.3(0.4)^{\mathrm{ab}}$ & $0.5(0.3)^{\mathrm{ab}}$ & $4.0(0.5)^{\mathrm{a}}$ & $29(3)^{\mathrm{a}}$ & $15(2)^{\mathrm{ab}}$ \\
\hline \multirow[t]{2}{*}{ Limestone } & $5.2(0.5)^{\mathrm{ab}}$ & $5.3(0.9)^{\mathrm{bc}}$ & $0.2(0.1)^{\mathrm{a}}$ & $4.0(0.5)^{\mathrm{a}}$ & $41(3)^{\mathrm{c}}$ & $13(1)^{\mathrm{a}}$ \\
\hline & \multicolumn{2}{|c|}{ Respiration $\left(\mathrm{mg} \mathrm{kg}^{-1} \mathrm{day}^{-1}\right)$} & \multicolumn{2}{|c|}{ Net $\mathrm{N}$-mineralization $\left(\mathrm{mg} \mathrm{kg}^{-1} \mathrm{day}^{-1}\right)$} & \multicolumn{2}{|c|}{$\mathrm{NM}$ per unit $\mathrm{C}$ respired $\left(\mathrm{mg} \mathrm{g}^{-1}\right)$} \\
\hline \multicolumn{7}{|l|}{ Beech } \\
\hline Acid marl & $2,179(588)^{\mathrm{a}}$ & $63(17)^{\mathrm{a}}$ & $10(12)^{\mathrm{a}}$ & $1.3(0.5)^{\mathrm{b}}$ & $5(6)^{\mathrm{a}}$ & $18(8)^{\mathrm{a}}$ \\
\hline Limestone & $1,627(476)^{\mathrm{a}}$ & $59(14)^{\mathrm{a}}$ & $15(9)^{\mathrm{a}}$ & $0.3(0.5)^{\mathrm{a}}$ & $11(10)^{\mathrm{a}}$ & $9(5)^{\mathrm{a}}$ \\
\hline \multicolumn{7}{|l|}{ Hornbeam } \\
\hline Acid marl & $1,858(291)^{\mathrm{a}}$ & $45(9)^{\mathrm{a}}$ & $3(2)^{\mathrm{a}}$ & $1.0(0.5)^{\mathrm{ab}}$ & $2(1)^{\mathrm{a}}$ & $19(3)^{\mathrm{a}}$ \\
\hline Limestone & $3,608(454)^{\mathrm{b}}$ & $43(10)^{\mathrm{a}}$ & $11(6)^{\mathrm{a}}$ & $0.3(0.5)^{\mathrm{a}}$ & $3(2)^{\mathrm{a}}$ & $13(9)^{\mathrm{a}}$ \\
\hline
\end{tabular}

Mean values $(n=4)$ and standard deviations. Different letters indicate significant differences between species and/or parent materials for a particular soil parameter $(P<0.025$, due to Bonferroni corrections)

$S O M$ soil organic matter, $N M$ per unit $C$ respired net $\mathrm{N}$-mineralization per unit $\mathrm{C}$ respired, organic organic layer, Ah mineral topsoil

However, correlations between gross and net N-mineralization were negative $\left(R^{2}=0.90\right)$. Sandstone showed low gross, but high net $\mathrm{N}$-mineralization, more or less independent of species, and limestone the opposite. If the contribution of the mineral topsoil was made more important for acid marl and limestone, and values multiplied with factor 1.5 and 2 respectively, $R^{2}$ decreased to 0.89 , but response patterns did not change. If mineral topsoil values were even further increased with factor 2 for acid marl and 3 for limestone, $R^{2}$ decreased to 0.84 , but still showed a negative relationship between total gross and net $\mathrm{N}$-mineralization.

\section{Discussion}

The objective of this study was to further examine differences in N-dynamics between acid and calcareous soil, and to explore whether litter quality could possibly alter these response patterns. The results clearly point to differences in microbial behaviour and net $\mathrm{N}$-mineralization, especially between sites. Naturally, a laboratorium incubation experiment does not reflect actual $\mathrm{N}$-availability to the vegetation, because plant roots were excluded, and root competition absent (e.g. Schimel and Bennett 2004; Chapman et al. 2006). Also, deeper soil layers were not studied, and earthworms excluded, which may increase $\mathrm{N}$-availability by excretion of $\mathrm{N}$ in urine, mucoproteins and dead tissue (Scheu 1997), although leaching of mineral N from worm casts in lime-rich beech forest may be lower than in arable löss soil (Marhan and Scheu 2005).

Interpretation of differences in respiration and net $\mathrm{N}$-mineralization over soil gradients was improved by the use of modelled gross $\mathrm{N}$-mineralization and immobilization, even if they should be seen as indicative only. Values were not actually measured, and, like in more common methods used to calculate gross N-mineralization (Schimel 1988; Booth et al. 2005), the model equations are based on hardto-verify assumptions, such as processing of $\mathrm{C}$ and $\mathrm{N}$ according to existing $\mathrm{C}: \mathrm{N}$ ratios, which are partly measured in inhomogeneous substrates. Nevertheless, in accord with Hart et al. (1994), modelled gross N-mineralization and measured respiration were closely correlated, with $\mathrm{R}^{2}$ values of 0.97 for the organic layer and 0.79 for the mineral topsoil, which suggests that the model at least provides realistic estimates. Also, the modelled increase in immobilization from sandstone and acid marl to limestone was supported by a measured decrease in efficiency of net $\mathrm{N}$-mineralization per unit $\mathrm{C}$ respired. The model even provided estimates over the entire incubation period, in contrast to the ${ }^{15} \mathrm{~N}$ pool dilution method (Schimel 1988; Booth et al. 2005), where gross $\mathrm{N}$-mineralization is measured in short-term experiments to avoid remineralization of added isotope (Hart et al. 1994). At a 30 day time scale, correlations between gross $\mathrm{N}$-mineralization and net $\mathrm{N}$-mineralization became very low (Booth et al. 2005), probably mainly because gross $\mathrm{N}$-mineralization was based on short-term and net N-mineralization on longer-term measurements. Even if not (yet) 

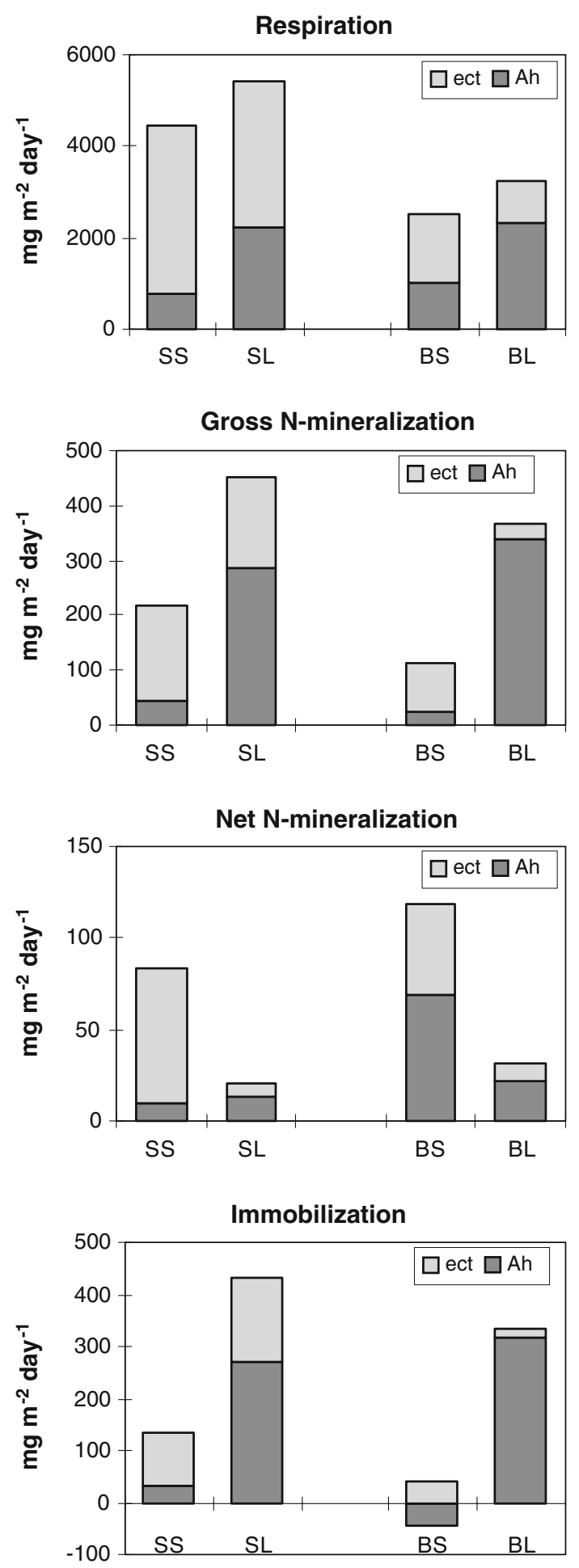

Fig. 1 Respiration, gross N-mineralization, net N-mineralization and immobilization in organic layer $(e c t)$ and mineral topsoil $(A h)$ for spruce and beech on sandstone and limestone. Mean values of respiration and net $\mathrm{N}$-mineralization were measured in a laboratory incubation experiment $(n=4)$; mean values of gross $\mathrm{N}$-mineralization and immobilization were calculated with a computer model, and based on four-factor perturbation tests $(n=16)$. SS spruce on sandstone, $S L$ spruce on limestone, $B S$ beech on sandstone, $B L$ beech on limestone
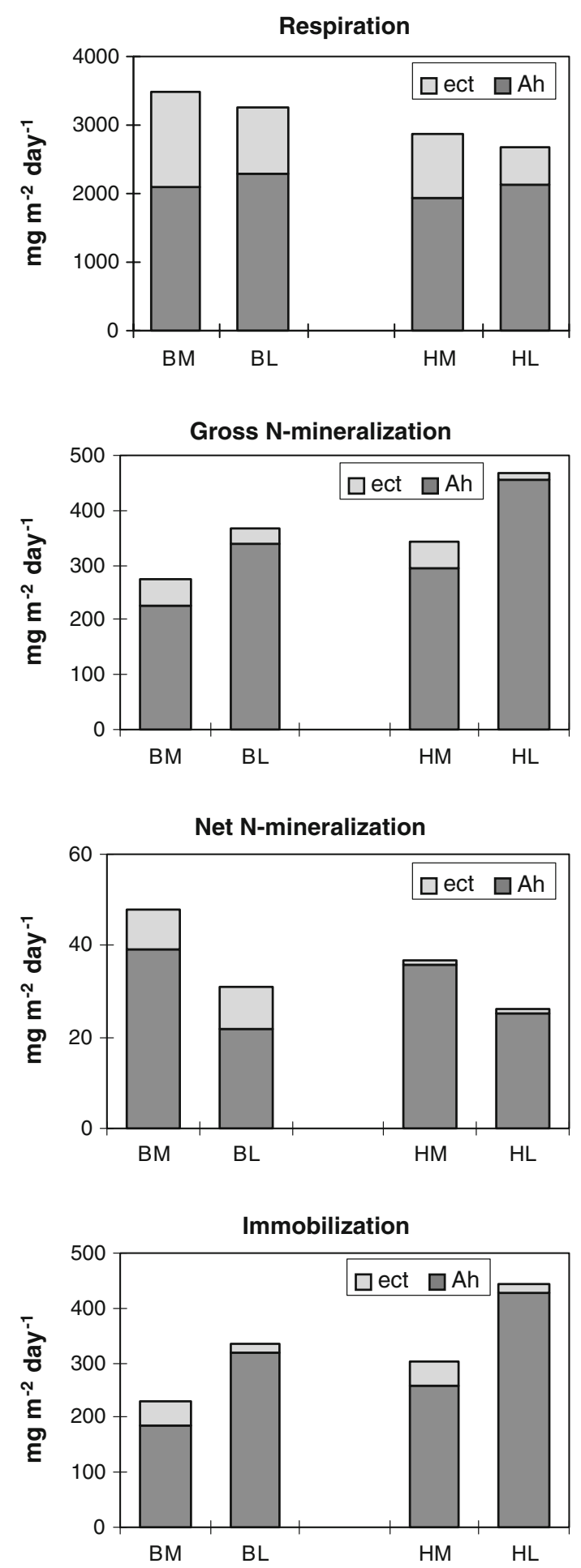

Fig. 2 Respiration, gross $\mathrm{N}$-mineralization, net $\mathrm{N}$-mineralization and immobilization in organic layer (ect) and mineral topsoil $(A h)$ for beech and hornbeam on acid marl and limestone. Mean values of respiration and net $\mathrm{N}$-mineralization were measured in a laboratory incubation experiment $(n=4)$; mean values of gross $\mathrm{N}$-mineralization and immobilization were calculated with a computer model, and based on four-factor perturbation tests $(n=16)$. $B M$ beech on acid marl, $B L$ beech on limestone, $H M$ hornbeam on acid marl, $H L$ hornbeam on limestone 


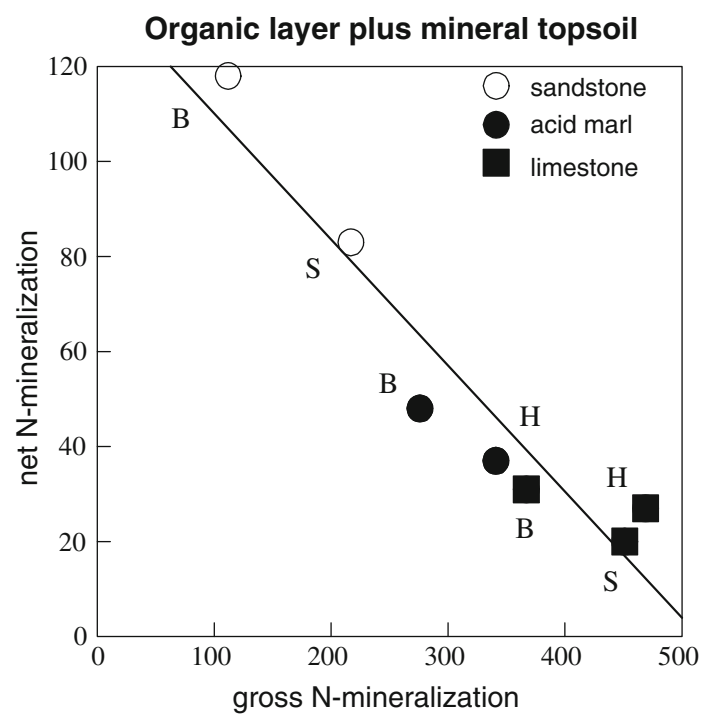

Fig. 3 The relationship between gross and net N-mineralization of organic layer and mineral topsoil combined $\left(\mathrm{mg} \mathrm{m}^{-2}\right.$ day $\left.^{-1}\right)$ in Luxembourg forests with different species (spruce, beech and hornbeam), growing on parent materials sandstone, acid marl and/or limestone $\left(n=7 ; R^{2}=0.90\right)$. Each data point is based on mean values for net $\mathrm{N}$-mineralization $(n=4$; measured in a laboratory incubation experiment) and modelled gross $\mathrm{N}$-mineralization ( $n=16$; derived from four factor perturbation tests). $S$ spruce, $B$ beech and $H$ hornbeam

supported by data, the model may thus provide a way to explore relationships between gross and net N-mineralization over longer periods. In accord with Cookson et al. (2006), who found that $\mathrm{pH}$ was important in predicting both $\mathrm{N}$-mineralization and immobilization, estimation of gross $\mathrm{N}$-mineralization and immobilization further support that $\mathrm{N}$-dynamics differed between species, but especially between parent materials.

\section{Differences in $\mathrm{N}$-cycling between species}

Differences between spruce and beech, or beech and hornbeam, were mainly found in the organic layer. In accord with expectations (Ponge 2003), the more recalcitrant species had generally higher mass, and higher contribution of the organic layer to total N-dynamics. Also, as expected (e.g. Swift et al. 1979; Scheu 1997; van der Krift and Berendse 2001; Högberg et al. 2006; Parton et al. 2007), less recalcitrant species showed higher rates of respiration and net $\mathrm{N}$-mineralization, if significantly so only for beech compared to spruce. Beech had also higher net $\mathrm{N}$-mineralization per unit $\mathrm{C}$ respired than spruce, even in the mineral topsoil, which may be due to its higher N-content (Bagherzadeh 2004; Zhang and Makeschin 2004). However, in accord with the latter authors, beech and spruce did not differ in net $\mathrm{N}$-mineralization per square metre, partly because spruce compensated lower process rates with higher mass of the organic layer. Also, beech and spruce had similar total net $\mathrm{N}$-mineralization when organic layer and mineral topsoil were combined. Hornbeam and beech did not even differ in process rates, let alone in net $\mathrm{N}$-mineralization per square metre, despite higher litter $\mathrm{N}$-content for hornbeam.

Different litter quality, but similar net $\mathrm{N}$-mineralization has also been reported for North American conifers and hardwoods (Reich et al. 1997; Campbell and Gower 2000), and is supported by a comparison of beech and hornbeam over a larger soil gradient (Kooijman and Martinez-Hernandez 2009). However, the lack of litter quality effects on $\mathrm{N}$-cycling seems contradictive to other literature reports (e.g. Scheu 1997; van der Krift and Berendse 2001; Högberg et al. 2006; Parton et al. 2007). However, when looking more closely, effects of higher litter quality may partly be attributed to higher litter input, which may also increase (van der Krift and Berendse 2001; Högberg et al. 2006). Also, litter quality may only lead to significant changes in $\mathrm{N}$-dynamics when initial $\mathrm{N}$-content is very high, or variation between litter types rather large (Högberg et al. 2006; Parton et al. 2007). For example, in Scheu (1997), net N-mineralization increased when nettle litter was applied, which had initial N-content of $43 \mathrm{mg} \mathrm{g}^{-1}$. Also, initial $\mathrm{N}$-content varied from 11 to $29 \mathrm{mg} \mathrm{g}^{-1}$ in Högberg et al. (2006), and from 4 to $20 \mathrm{mg} \mathrm{g}^{-1}$ in Parton et al. (2007). However, in our study, even though litter decomposition in the organic layer was clearly affected, initial $\mathrm{N}$-contents probably ranged from 8 to $14 \mathrm{mg} \mathrm{g}^{-1}$, which may have been too small for large effects on $\mathrm{N}$-cycling. Also, initial litter $\mathrm{N}$-content may have increased compared to natural levels by high atmospheric N-deposition, which further masks differences between species (Gundersen et al. 1998; Sah 2005). However, differences between species may also be overruled by different soil conditions. Reich et al. (1997) showed that differences in net $\mathrm{N}$-mineralization between conifers and hardwoods disappeared when compared on similar soils. Also, differences between species are often tested with litterbags (e.g., Parton et al. 2007), which reduce access of soil macrofauna. In reality, however, incorporation of litter in the mineral soil is one of the most important differences between acid and calcareous soil (Ponge 2003), which affects $\mathrm{C}$ and $\mathrm{N}$-cycling in both organic layer and mineral soil. In our study, where parent materials so clearly differed, it is likely that litter quality effects (if present) were at least partly modified by soil conditions and microbial behaviour.

Differences in $\mathrm{N}$-cycling between parent materials

In accord with expectations (Aerts and Chapin 2000; Ponge 2003; Schimel and Bennett 2004), sandstone had 
generally lower respiration and gross $\mathrm{N}$-mineralization than limestone, and contribution of the organic layer was more important. However, net N-mineralization was generally higher on sandstone than on limestone, whether expressed as process rates, per unit $\mathrm{C}$ respired or per square metre. This is supported by field and laboratory studies, which reported higher net N-mineralization for acid than calcareous soil as well (Zöttle 1960; Davy and Taylor 1974; Verhoeven et al. 1990; Kooijman and Besse 2002; Kooijman et al. 2008, Kooijman and Hedenäs 2009). Sandstone and limestone also differ in soil texture, but sandy soils had generally higher net $\mathrm{N}$-mineralization than loamy soils as well (Hassink et al. 1993; Hassink 1994). This effect of soil texture was not supported by the results from Reich et al. (1997), but in that study, higher net N-mineralization for loamy alfisols than sandy entisols could also be attributed to higher soil moisture and temperature, as alfisols only occurred at lower latitudes. Differences between acid marl and limestone, which only differ in $\mathrm{pH}$, were smaller, but in the mineral topsoil, net $\mathrm{N}$-mineralization rates were also lower for limestone than for acid marl.

Net N-mineralization may not be considered synonymous to $\mathrm{N}$-availability to the vegetation, as plant roots take up organic $\mathrm{N}$ and compete for inorganic $\mathrm{N}$ with microbes (Schimel and Bennett 2004; Chapman et al. 2006). However, even if plant roots profit from higher rates of depolymerization at high $\mathrm{pH}$, this does not explain why net $\mathrm{N}$-mineralization is not high as well. In the organic layer, high net $\mathrm{N}$-mineralization in sandstone may be partly attributed to more advanced stages of decomposition and lower $\mathrm{C}: \mathrm{N}$ ratios. In the mineral topsoil, however, $\mathrm{C}: \mathrm{N}$ ratios were lower on limestone. Low net $\mathrm{N}$-mineralization on limestone, as well as the negative relationship between total gross and net $\mathrm{N}$-mineralization, may be related to shifts in microbial communities between parent materials. Acid soils are generally dominated by fungi, and calcareous soils by bacteria (Blagodatskaya and Anderson 1998; Bååth and Anderson 2003). Also, fungi are more common in sandy soils, and bacteria in loamy soils (Hassink et al. 1993; Hassink 1994), because fungi live in air-filled pore space, while bacteria occupy smaller water-filled pores (Moore et al. 2005). Apart from niches, bacteria and fungi may also differ in microbial activity and N-requirements. High bacterial N-demand may to some extent be explained by lower $\mathrm{C}: \mathrm{N}$ ratios compared to fungi (Hassink 1994; Moore et al. 2005), but bacteria may also need more $\mathrm{N}$ due to high rates of cell division, and because they use amino-acids as osmoregulator rather than carbohydrates (e.g. Measures 1975; Kuehn et al. 1998). On sandstone, high fungi may thus explain low gross N-mineralization, but also low immobilization, and as such relatively high net $\mathrm{N}$-mineralization.
On limestone, and to some extent acid marl, high amounts of bacteria may increase gross $\mathrm{N}$-mineralization, but at the same time immobilization, and thus reduce net N-mineralization. Microbial N may partly be recycled, but Sjöberg and Persson (1998) showed that, although ${ }^{15} \mathrm{~N}$ was initially mainly found in microbial mass, after 5 months it had become incorporated in stable soil organic matter.

As indicated before, laboratory incubation experiments do not reflect actual $\mathrm{N}$-availability to the vegetation. In the field, high microbial N-demand and low net N-mineralization in calcareous soils may be mitigated by e.g., earthworms, which produce N-rich casts (Scheu 1997; Marhan and Scheu 2005). However, there are some indications that lime-rich soils may have low $\mathrm{N}$-availability indeed. Marhan and Scheu (2005) suggested that mineral nitrogen in worm casts was immobilized by microorganisms in lime-rich beech forests, in contrast to arable soil. Also, beech seedlings had lower N-content when grown in limerich than in acid soil (Wolters and Stickan 1991). In addition, N-content of fresh beech litter was consistently lower on calcareous than acid soil (Kooijman et al. 2008). Nevertheless, in reality, acid and lime-rich soils may not differ in actual availability of $\mathrm{N}$, but rather in strategy to sustain this.

\section{Concluding remarks}

The results of this laboratory study suggest that litter quality may affect N-dynamics, but primarily in the organic layer. Differences between species were minor when forest floor and mineral topsoil were combined, and possibly overruled by soil conditions and microbial behaviour. In contrast, parent materials showed clear differences in $\mathrm{N}$-cycling, independent of species. Limestone seemed to have higher gross N-mineralization than sandstone and acid marl. However, this study further supports that net $\mathrm{N}$-mineralization may be limited by high microbial $\mathrm{N}$-demand in lime-rich soil, at least in incubation experiments were root competition is low and earthworms absent. Net $\mathrm{N}$-mineralization may be low despite high gross $\mathrm{N}$-release, because immobilization is also high. In contrast, sandstone may have higher net $\mathrm{N}$-mineralization than expected, despite low gross $\mathrm{N}$-mineralization, because immobilization is low as well.

Acknowledgments We thank Jan Sevink, Jan van Mourik and Bas van Dalen for support and helpful discussions. Technical assistance was supplied by Leo Hoitinga, Joke Westerveld and Piet Wartenbergh.

Open Access This article is distributed under the terms of the Creative Commons Attribution Noncommercial License which permits any noncommercial use, distribution, and reproduction in any medium, provided the original author(s) and source are credited. 


\section{References}

Aerts MAPA, Chapin FS (2000) The mineral nutrition of wild plants revisited: a re-evaluation of process and patterns. Adv Ecol Res 30:1-67. doi:10.1016/S0065-2504(08)60016-1

Aubert M, Hedde M, Decaens T, Bureau F, Margerie P, Alard D (2003) Effects of tree canopy composition on earthworms and other macro-invertebrates in beech forests of Upper Normandy (France). Pedobiologia (Jena) 47:904-912

Bååth E, Anderson TH (2003) Comparison of soil fungal/bacterial ratios in a $\mathrm{pH}$ gradient using physiological and PLFA-based techniques. Soil Biol Biochem 35:955-963. doi:10.1016/S00380717(03)00154-8

Bagherzadeh A (2004) Mechanisms of carbon and nitrogen tranformations in forest floors of beech, spruce and mixed beechspruce-stands. Ph.D. thesis, Georg-August Universität Göttingen

Berendse F, Bobbink R, Rouwenhorst G (1989) A comparative study on nutrient cycling in wet heathland ecosystems. II. Litter decomposition and nutrient mineralization. Oecologia 78:338348. doi:10.1007/BF00379107

Blagodatskaya EV, Anderson TH (1998) Interactive effects of $\mathrm{pH}$ and substrate quality on the fungal-to-bacterial ratio and $\mathrm{qCO}_{2}$ of microbial communities in forest soils. Soil Biol Biochem 30:1269-1274. doi:10.1016/S0038-0717(98)00050-9

Booth MS, Stark JM, Rastetter E (2005) Controls of nitrogen cycling in terrestrial ecosystems: a synthetic analysis of literature data. Ecol Monogr 75:139-157. doi:10.1890/04-0988

Campbell JL, Gower ST (2000) Detritus production and soil N transformations in old-growth eastern hemlock and sugar maple stands. Ecosystems 3:185-192. doi:10.1007/s100210000018

Chapman SK, Langley JA, Hart SC, Koch GW (2006) Plants actively control nitrogen cycling: uncorking the microbial bottleneck. New Phytol 169:27-34. doi:10.1111/j.1469-8137.2005.01571.x

Cookson WR, Osmar M, Marschner P, Abaye DA, Clark I, Murphy DV, Stockdale EA, Watson CA (2006) Controls on soil nitrogen cycling and microbial community composition across land use and incubation temperature. Soil Biol Biochem 39:744-756. doi: 10.1016/j.soilbio.2006.09.022

Davy AJ, Taylor K (1974) Seasonal patterns of nitrogen availability in contrasting soils in the Chiltern Hills. J Ecol 62:793-807. doi: $10.2307 / 2258955$

Green RN, Trowbridge RL, Klinka K (1993) Towards a taxonomic classification of humus forms. Suppl For Sci 39:1-49

Gundersen P, Callesen I, de Vries W (1998) Nitrate leaching in forest ecosystems is related to forest floor $\mathrm{C} / \mathrm{N}$ ratios. Environ Pollut 102:403-407. doi:10.1016/S0269-7491(98)80060-2

Hart SC, Nason GE, Myrold DD, Perry DA (1994) Dynamics of gross nitrogen transformations in an old growth forest: the carbon connection. Ecology 75:880-891. doi:10.2307/1939413

Hassink J, Bouwman LA, Zwart KB, Bloem J, Brussaard L (1993) Relationships between soil texture, soil structure, physical protection of organic matter, soil biota and $\mathrm{C}$ and $\mathrm{N}$ mineralization in grasslands soils. Geoderma 57:105-128. doi:10.1016/ 0016-7061(93)90150-J

Hassink J (1994) Effects of soil texture and grassland management on soil organic $\mathrm{C}$ and $\mathrm{N}$ and rates of $\mathrm{C}$ and $\mathrm{N}$ mineralization. Soil Biol Biochem 26:1221-1231. doi:10.1016/0038-0717(94)90147-3

Henderson-Sellers B, Henderson-Sellers A (1993) Factorial techniques for testing environmental model sensitivity. In: Jakeman AJ, Beck MB, McAleer MJ (eds) Modelling change in environmental systems. Wiley, Chichester

Högberg MN, Myrold DD, Giesler R, Högberg P (2006) Contrasting patterns of soil $\mathrm{N}$-cycling in model ecosystems of Fennoscandian boreal forests. Oecologia 147:96-107. doi:10.1007/s00442-005$0253-7$
Kooijman AM, Besse M (2002) On the higher availability of $\mathrm{N}$ and $\mathrm{P}$ in lime-poor than in lime-rich coastal dunes in the Netherlands. J Ecol 90:394-403. doi:10.1046/j.1365-2745.2001.00661.x

Kooijman AM, Kooijman-Schouten MM, Martinez-Hernandez GB (2008) Alternative strategies to sustain $\mathrm{N}$-fertility in acid and calcaric beech forests: low microbial $\mathrm{N}$-demand versus high biological activity. Basic Appl Ecol 9:410-421. doi:10.1016/ j.baae.2007.05.004

Kooijman AM, Hedenäs L (2009) Changes in nutrient availability from calcareous to acid wetland habitats with closely related brownmoss species: increase instead of decrease in $\mathrm{N}$ and $\mathrm{P}$. Plant Soil (in press)

Kooijman AM, Martinez-Hernandez GB (2009) Effects of litter quality and parent material on organic matter characteristics and $\mathrm{N}$-dynamics in Luxembourg beech and hornbeam forests. For Ecol Manage 257:1732-1739

Kuehn KA, Churchill PF, Suberkropp K (1998) Osmoregulatory responses of fungi inhabiting standing litter of the freshwater emergent macrophyte Juncus effusus. Appl Environ Microbiol 64:607-612

Laskowski R, Niklinska M, Maryanski M (1995) The dynamics of chemical elements in forest litter. Ecology 76:1393-1406. doi: $10.2307 / 1938143$

Marhan S, Scheu S (2005) Effects of sand and litter availability on organic matter decomposition in soil and in casts of Lumbricus terrestris L. Geoderma 128:155-166. doi:10.1016/j.geoderma. 2004.07.001

Measures JC (1975) Role of amino acids in osmoregulation of nonhalophilic bacteria. Nature 257:398-400. doi:10.1038/257398a0

Moore JC, McCann K, de Ruiter PC (2005) Modeling trophic pathways, nutrient cycling, and dynamic stability in soils. Pedobiologia (Jena) 49:499-510. doi:10.1016/j.pedobi.2005.05.008

Parton WP, Silver WL, Burke IC, Grassens L, Harmon ME, Currie WS, King JY, Adair EC, Brandt LA, Hart SC, Fasth B (2007) Global-scale similarities in nitrogen release patterns during longterm decomposition. Science 315:361-364. doi:10.1126/science. 1134853

Ponge JF (2003) Humus forms in terrestrial ecosystems: a framework to biodiversity. Soil Biol Biochem 35:935-945. doi:10.1016/ S0038-0717(03)00149-4

Reich PB, Grigal DF, Aber JD, Gower ST (1997) Nitrogen mineralization and productivity in 50 hardwood and conifer stands on diverse soils. Ecology 78:335-347

Sah SP (2005) ${ }^{15} \mathrm{~N}$ natural abundance in two podzol soils of two spruce forests differing in their atmospheric $\mathrm{N}$ deposition conditions. Plant Soil Environ 51:416-422

SAS Institute Inc (1985) SAS user's guide: statistics. 1982 edn. SAS, Cary

Schimel DS (1988) Calculation of microbial growth efficiency from ${ }^{15} \mathrm{~N}$ immobilization. Biogeochemistry 6:239-243. doi:10.1007/ BF02182998

Schimel JP, Bennett J (2004) Nitrogen mineralization: challenges of a changing paradigm. Ecology 85:591-602. doi:10.1890/03-8002

Scheu S (1997) Effects of litter (beech and stinging nettle) and earthworms (Octolasion lacteum) on carbon and nutrient cycling in beech forests on a basalt-limestone gradient: a laboratory experiment. Biol Fertil Soils 24:384-393. doi:10.1007/ s003740050262

Scott NA, Binkley D (1997) Foliage litter quality and annual net N-mineralization: comparison across North American forest sites. Oecologia 111:151-159. doi:10.1007/s004420050219

Sjöberg RM, Persson T (1998) Turnover of carbon and nitrogen in coniferous forest soils of different $\mathrm{N}$-status and under different $15 \mathrm{NH}_{4}-\mathrm{N}$ application rate. Environ Pollut 102:385-393. doi: 10.1016/S0269-7491(98)80058-4 
Swift MJ, Heal OW, Anderson JM (1979) Decomposition in terrestrial ecosystems. University of California Press, Berkeley

Tietema A (1992) Nitrogen cycling and soil acidification in forest ecosystems in the Netherlands. Ph.D. thesis, University of Amsterdam

Tietema A, Wessel WW (1992) Gross nitrogen transformations in the organic layer of acid forest ecosystems subjected to increased atmospheric nitrogen input. Soil Biol Biochem 24:943-950. doi: 10.1016/0038-0717(92)90021-O

van der Krift TAJ, Berendse F (2001) The effect of plant species on soil nitrogen mineralization. J Ecol 89:555-561. doi:10.1046/ j.0022-0477.2001.00580.x

van der Werf S (1991) Bosgemeenschappen; Natuurbeheer in Nederland deel 5. Pudoc, Wageningen
Verhoeven JTA, Maltby E, Schmitz MB (1990) Nitrogen and phosphorus mineralization in fens and bogs. J Ecol 78:713726. doi: $10.2307 / 2260894$

Westerman RL (1990) Soil testing and plant analysis, 3rd edn. Soil Science Society of America, Madison

Wolters V, Stickan W (1991) Resource allocation of beech seedlings (Fagus sylvatica L.) —relationship to earthworm activity and soil conditions. Oecologia 88:125-131. doi:10.1007/BF00328412

Zhang Z, Makeschin F (2004) Comparison of soil dynamics under beech, Norway spruce and scots pine in central Germany. Eur J For Res 123:29-37

Zöttle H (1960) Dynamik der Stickstoffmineralisation im Waldbodenmaterial. Plant Soil 8:207-223. doi:10.1007/BF01677502 